\begin{tabular}{|l|l|l||}
\hline \multicolumn{2}{|c|}{ PublisherInfo } \\
\hline \hline PublisherName & $:$ & BioMed Central \\
\hline \hline PublisherLocation & $:$ & London \\
\hline \hline PublisherImprintName & $:$ & BioMed Central \\
\hline \hline
\end{tabular}

\title{
A thousand northerns
}

\begin{tabular}{|l|l|l||}
\hline \multicolumn{2}{|c|}{ ArticleInfo } \\
\hline \hline ArticleID & $:$ & 4131 \\
\hline \hline ArticleDOI & $:$ & $10.1186 /$ gb-spotlight-20010627-01 \\
\hline \hline ArticleCitationID & $:$ & spotlight-20010627-01 \\
\hline \hline ArticleSequenceNumber & $:$ & 202 \\
\hline \hline ArticleCategory & $:$ & Research news \\
\hline \hline ArticleFirstPage & $:$ & 1 \\
\hline \hline ArticleLastPage & $:$ & 2 \\
\hline \hline & & RegistrationDate : 2001-06-27 \\
ArticleHistory & $:$ & OnlineDate $\quad$ 2001-06-27 \\
\hline \hline ArticleCopyright & $:$ & BioMed Central Ltd2001 \\
\hline \hline ArticleGrants & $:$ & \\
\hline \hline ArticleContext & $:$ & 130592211 \\
\hline \hline
\end{tabular}




\section{Jonathan B Weitzman}

Email: jonathanweitzman@hotmail.com

The Transcription Consortium of the EUROFAN network set itself the task of generating a large set of gene expression data in yeast using classical northern analysis. In the June 15 EMBO Journal, Brown et al. present the results of analysing over 1,000 genes in yeast under eight different physiological conditions (EMBO J 2001, 20:3177-3186). These include mid-exponential phase growth, and various physiological stress conditions. The five member laboratories of the Consortium paid especial attention to the standardizing of their RNA and hybridization protocols. They used algorithms to 'mine' the data and perform cluster analysis. This analysis enabled them to assign potential functions to clusters of ORFs. They compared the northern blot data for 1,008 ORFs with that generated by microarray analysis. Brown et al. claim that this is probably the 'largest set of transcription data that has ever been collected using this classical technique... and it is unlikely to be surpassed.' The authors urge the yeast research community to adopt standardized strains, growth conditions and data normalization procedures, in an attempt to generate reproducible and comparable transcriptome data.

\section{References}

1. Transcript analysis of 250 novel yeast genes from chromosome XIV

2. $E M B O J$, [http://www.emboj.org]

3. S. cerevisiae - EUROFAN B2 Node, [http://www.mips.biochem.mpg.de/proj/eurofan/eurofan_1/b2/]

4. Cluster analysis and display of genome-wide expression patterns.

5. Yeast research group, [http://www.yeastresearch.man.ac.uk]

6. Exploring the metabolic and genetic control of gene expression on a genomic scale. 